\title{
The Role of Digitalization in the Sustainable Development of Rural Settlements
}

\author{
Sergey Nikolaevich Mityakov \\ Department of Digital Economics \\ Nizhny Novgorod State Technical University named after \\ R.E. Alekseev \\ Russian Federation, Nizhny Novgorod \\ snmit@mail.ru \\ Tatyana Aleksandrovna Fedoseeva \\ Department of Digital Economics \\ Nizhny Novgorod State Technical University named after \\ R.E. Alekseev \\ Russian Federation, Nizhny Novgorod \\ fedoseeva-t@yandex.by
}

\author{
Evgeniy Sergeevich Mityakov \\ Department of Digital Economics \\ Nizhny Novgorod State Technical University named after \\ R.E. Alekseev \\ Russian Federation, Nizhny Novgorod \\ iyao@mail.ru \\ Irina Aleksandrovna Korotunova \\ Department of Foreign Languages \\ Nizhny Novgorod State Technical University named after \\ R.E. Alekseev \\ Russian Federation, Nizhny Novgorod \\ korotunova.irina@yandex.ru
}

\begin{abstract}
The article is devoted to the issues of rural settlements sustainable development. It is shown that the key task of ensuring the sustainable development of such settlements is creation of effective monitoring systems. A review of existing studies on sustainable development of territories is given. It is shown that, despite the variety of scientific works devoted to various methods of assessing the region's economic condition, the problem of sustainable development assessment of rural settlements remained outside these studies. The authors proposed a new indicators system for the sustainable development of rural settlements, which was tested on the example of the Diveevo district, located in the southern part of the Nizhny Novgorod region. The analysis of the socio-economic status of six rural settlements in the area showed a generally negative dynamics of their sustainable development. A similar dynamics, apparently, is observed in a number of other rural areas of the country. One of the possible mechanisms for increasing the level of socio-economic development of rural settlements is the widespread introduction of digital economy. An example of successful digitalization experience of the Michurinsk rural settlement of Khabarovsk Territory is given.
\end{abstract}

Keywords: digital economy, sustainable development, rural settlements, monitoring, system of indicators, dynamics analysis

\section{INTRODUCTION}

In accordance with the Sustainable Development Concept of the Russian Federation Rural Territories for the Period until 2030 [1], the most important strategic goals of state policy are identified - creating conditions for sustainable development and identifying key problems in rural areas; the solution of these problems will allow to ensure food security, increase competitiveness of the Russian economy and citizens' welfare. To achieve these goals, it seems appropriate to monitor the sustainable economic development of rural settlements. An analysis of foreign and domestic papers on the assessment of the economic development level showed that one of the main problems is the choice of indicators, on the basis of which models are built and the results are analyzed. At present, there is no unified system of sustainable development indicators for rural settlements.

The importance of monitoring the sustainable development of rural municipalities is the timely identification of the negative processes that threaten the sustainability of the economy and the social sphere of the settlement, assessment of the negative processes nature and extent, identification and prevention of crisis situations. Another important aspect of such monitoring is the assessment of the digitalization impact on the sustainable development of rural settlements.

\section{METHODS}

Among foreign models, the one proposed by J. Hacker [2] can be noted. It puts forward the model to assess economic stability through the Economic Security Index (ESI), which considers not only household resources, but also the cost of medical care, which is the most important indicator of changes in the financial well-being of citizens. The model proposed by Glaser and Tobio [3] includes elasticity of demand in the housing market. The volume of home sales in the primary and secondary market may give an idea of consumer optimism (consumer confidence). D. Krupka and K. Donaldson [4] pay special attention to the environmental component, the 
monitoring systems. It is shown that, depending on the type of municipalities, the indicators system may change. The author's system of indicators for urban districts which consists of twenty-six indicators in the context of twelve projections is presented. The system has been successfully tested in urban districts of the Nizhny Novgorod region.

his paper presents a system of rural settlements sustainable development indicators, which is tested on the example of the Diveevo district, located in the southern part of the Nizhny Novgorod region. As a part of the local selfgovernment organization, the Diveevo municipal district includes six municipalities with the rural settlements status. Agriculture is developed on the territory of the district, construction materials are produced. Table 1 shows the main indicators characterizing economic and social development of rural settlements at the Diveyevskiy district in 2018 .

The analyzed results are as follows. The number of stores in the settlements varies from three to seven and the number of sports facilities - from three to five per 1000 people. Solid municipal waste is not removed at all in the Glukhovsky and Ivanovo settlements, which indicates a problem in the environmental sphere of these settlements. Residential premises in almost all settlements are at an acceptable level of 28 to $35 \mathrm{~m} 2$ per person. The indicator "Investments in fixed assets" has a large variation. This is due to the unstable financial condition of the settlements, which is a threat to their sustainable economic development. The indicator reflecting the condition of paved roads has the lowest value in the village of Satiss, about $3 \mathrm{~km}$ per inhabitant, which may negatively affect further development of this settlement. "stability zone" and "leaders", tested on the basis of the Ulyanovsk region. In [14], an indicative dynamic technique for assessing changes in the security state of a regional economy is described. The technique was used to assess the economic security level of the Sverdlovsk region.

In [15] it is shown that the factor influencing increase of economic safety level of municipalities is sufficient providing of these unities with the main engineering communications. As shown in [16], an important factor in ensuring the economic security of municipalities is the spatial factor, that is, uniting the settlements with labor mobility, industrial relations, a general transport and engineering infrastructure, a single network of social and cultural services and recreation areas. Transport accessibility to the central settlement of the economic and administrative centres of the neighbouring territories plays an important role.

Despite the variety of scientific papers devoted to various assessment methods of regions' economic condition, the municipal entities, the selection of indicators assessing their sustainable economic development, the problem of sustainable development assessment of a municipal area and its rural settlements remained beyond the scope of research. Among such works we can single out only the article [17], where the methodological approach to the development of rural areas sustainable development indicators is proposed.

\section{RESULTS}

In [18] it was shown that the key task of ensuring the economic security of the municipality is creation of effective 
Declines in population are widespread and are due to both

TABLE I. INDICATORS OF SUSTAINABLE DEVELOPMENT OF RURAL SETTLEMENTS IN DIVEEVSKY DISTRICT NIZHNY NOVGOROD REGION

\begin{tabular}{|c|c|c|c|c|c|c|c|}
\hline \multirow[b]{2}{*}{ № } & \multirow[b]{2}{*}{$\begin{array}{l}\text { Name of the } \\
\text { indicator }\end{array}$} & \multicolumn{6}{|c|}{ Settlement } \\
\hline & & 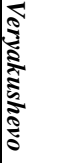 & 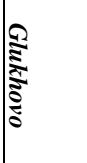 & 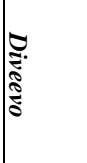 & 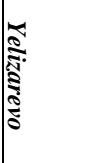 & 竎 & 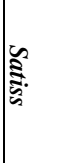 \\
\hline 1 & $\begin{array}{l}\text { Number of shops } \\
\text { per } \quad 1000 \\
\text { inhabitants, units }\end{array}$ & 5.65 & 5.56 & 6.94 & 5.18 & 7.22 & 3.37 \\
\hline 2 & $\begin{array}{l}\text { Number of sports } \\
\text { facilities per } 1000 \\
\text { inhabitants, units }\end{array}$ & 4.71 & 3.18 & 2.87 & 3.89 & 2.88 & 5.24 \\
\hline 3 & $\begin{array}{lr}\begin{array}{l}\text { Removal } \\
\text { municipal }\end{array} \text { of } \\
\text { waste per } 1 \\
\text { resident, cubic } \\
\text { meters }\end{array}$ & 0.09 & 0.00 & 1.18 & 0.25 & 0.00 & 1.57 \\
\hline 4 & $\begin{array}{l}\text { Living space per } 1 \\
\text { inhabitant, } \mathrm{m}^{2}\end{array}$ & 35.1 & 28.9 & 35.9 & 35.0 & 33.7 & 31.5 \\
\hline 5 & $\begin{array}{l}\text { Investments in } \\
\text { fixed capital per } 1 \\
\text { inhabitant, } \\
\text { thousand nubles }\end{array}$ & $\begin{array}{l}0.00 \\
0 \\
\end{array}$ & $\begin{array}{l}1.62 \\
6 \\
\end{array}$ & $\begin{array}{l}67.2 \\
07 \\
\end{array}$ & $\begin{array}{l}0.27 \\
9 \\
\end{array}$ & $\begin{array}{l}0.97 \\
3 \\
\end{array}$ & $\begin{array}{l}26.1 \\
68 \\
\end{array}$ \\
\hline 6 & $\begin{array}{l}\text { Length of paved } \\
\text { roads per } 1.000 \\
\text { inhabitants, } \mathrm{km}\end{array}$ & 17.4 & 9.30 & 7.48 & 11.5 & 17.9 & 3.03 \\
\hline 7 & $\begin{array}{l}\text { Local budget } \\
\text { balance in relation } \\
\text { to the amount of } \\
\text { revenues, } \%\end{array}$ & 3.85 & -2.4 & -0.3 & 5.68 & -1.4 & -0.7 \\
\hline 8 & $\begin{array}{l}\text { Share of own } \\
\text { funds in local } \\
\text { budget revenues, } \%\end{array}$ & 100 & 33.6 & 22.0 & 41.7 & 24.2 & 75.7 \\
\hline 9 & $\begin{array}{l}\text { Natural population } \\
\text { growthrate,ppm }\end{array}$ & -3.7 & -13.51 & -6.70 & -16.8 & -13.7 & -7.87 \\
\hline 10 & $\begin{array}{l}\text { Migration growth } \\
\text { rate,ppm }\end{array}$ & $\begin{array}{l}- \\
14.1 \\
\end{array}$ & -25.4 & -5.38 & 1.29 & -14.4 & -36.3 \\
\hline 11 & $\begin{array}{l}\text { Number of } \\
\text { treatment and } \\
\text { prevention } \\
\text { organizations per } \\
1000 \text { inhabitants, } \\
\text { units }\end{array}$ & 3.77 & 2.38 & 0.48 & 2.59 & 2.89 & 0.37 \\
\hline 12 & $\begin{array}{l}\text { Proportion of local } \\
\text { budget expenditure } \\
\text { allocated to culture } \\
\text { and film, } \%\end{array}$ & 0.00 & 0.00 & 13.5 & 0.00 & 0.00 & 0.00 \\
\hline 13 & $\begin{array}{l}\text { Commissioning of } \\
\text { residential } \\
\text { buildings per } \\
\text { capita, m2 }\end{array}$ & 0.00 & 0.04 & 1.02 & 0.63 & 0.00 & 0.54 \\
\hline
\end{tabular}

The local budget has a surplus only in two of the six settlements. The budget deficit in other settlements does not exceed $2.4 \%$, which is a good result. The "Share of own funds" indicator also has a large spread in values. In the Ivanovo and Diveevo settlements, this indicator is $24 \%$ and $22 \%$, respectively. On the one hand, this means that own funds in the budget are insufficient, and on the other hand, that these settlements successfully attract free subsidies necessary for their sustainable economic development. As for Veryakushevo, where the budget is $100 \%$ made up of its own funds, the negative effect of the additional monetary funding lack is obvious. natural attrition and migration outflow. It should be noted here that demographic indicators (coefficient of natural population growth and coefficient of migration growth) require further research, which can be carried out considering age groups. The number of treatment and prevention organizations per 1000 inhabitants is minimal in Diveevo, although it is the largest settlement among those considered. This may be due to health care reform, which implies the enlargement and modernization of health care organizations. Apparently, in small villages, their number is greater than in large ones, due to the presence of small paramedic points. The indicator relating to expenses on culture and cinematography is nonzero only in Diveevo, in other settlements such activities are not financed and are not carried out. And finally, the indicator "Commissioning of residential buildings per 1 inhabitant" exceeds $1 \mathrm{~m} 2$ only in the largest settlement (Diveevo), the rest have a clear lack of funds.

\section{DISCUSSION}

Introduction of the digital economy in rural settlements can be considered from two perspectives: the use of digital technologies in agriculture and the social sphere. Both of these sectors are closely interconnected, the growth in agriculture is due to the growth of the social sphere and the economic development sustainability in this territory. In this regard, the task of introducing methods and tools of digital economy in the system of socio-economic development of rural settlements seems to be urgent.

Here is a typical example. A year ago Rostelecom announced creation of the first digital village in Russia. It became Michurinskoe rural settlement of Khabarovsk Territory [19]. To implement digital services in four settlements Rostelecom built fiber-optic communication lines with a length of more than $30 \mathrm{~km}$. The administrative body of the rural settlement introduced an electronic book for accounting agricultural land, agricultural machinery and domestic animals. The rural outpatient clinic provides online consultation of patients with specialists of the regional hospital. The school has implemented an information and library system that allows using educational and fiction literature in online and offline modes. A street video surveillance system has been launched to help ensure security in the streets of the settlement. Residents of rural areas can connect modern communication services: "Smart House", "Interactive TV", "Video Surveillance", and high-speed Internet. As the first results of a statistical survey of the Michurinsky rural settlement showed, the introduction of digitalization has a generally positive effect on the socioeconomic situation of the settlement.

This above example illustrates how digitalization changes the status of an area. In the near future, the attractiveness of a dwelling place will be determined not so much by its geopolitical location and size as by the presence of a modern digital life support ecosystem.

The paper presents the author's system of sustainable development indicators of rural settlements. As a result of monitoring the rural settlements at the Diveevo Municipal 
Social Sciences and Arts SGEM 2016, Albena, 2016, book 2, Vol. 4, pp. 663-670.

Area, the following conclusions can be made: with a genera decline in the population residing on the territory of the region, the population is concentrated at urban settlements of the district. In 2018, every thirty and every fortieth person respectively left Satiss and Glukhov, which is a very alarming sign. Most village councils do not take out solid municipal waste, there is no investment and practically no new residential buildings are being built. Such a generally negative dynamic of socio-economic development is observed in a significant number of rural settlements in the country.

One of the possible mechanisms for enhancing the sustainable development of rural settlements is the widespread introduction of digital economy tools. The State is currently allocating significant resources to the digital economy development. If these resources reach rural areas, the dynamics of sustainable development of rural settlements can be expected to improve.

\section{References}

[1] Government Decree of the Russian Federation, February 2, 2015 No. 151-r "On the Strategy for the sustainable development of rural territories of the Russian Federation for the period until 2030". [Electronic resource]. - URL: http://government.ru/docs/16757/

[2] J.S. Hacker, G. Huber, A. Nichols, P. Rehm, M. Schlesinger, R.G. Valletta, S. Craig, "The Economic Security Index: A New Measure for Research and Policy Analysis Measure for Research and Policy Analysis", Federal Reserve Bank of San Francisco working paper series, 2012, [Electronic resource], URL: https://www.frbsf.org/economicresearch/files/wp12-21bk.pdf

[3] E. Glaeser, K.Tobio, "The Rise of the Sunbelt", Southern Economic Journal, 2008, No. 74 (3), pp. 610-643

[4] D. Krupka, K. Donaldson, "Wages, Rents and Heterogeneous Moving Costs", Economic Inquiry, 2013, No. 51 (1), pp. 844-864.

[5] D.S. Rickman, S.D. Rickman, "Population Growth in High? Amenity Nonmetropolitan: What's the Prognosis?", Journal of Regional Science, 2011, No. 51 (5), pp. 863-879.

[6] S. Mityakov, O. Mityakova, E. Mityakov, D. Lapaev, "Structural approach to the analysis of sustainable development of economic systems", 3rd International Multidisciplinary Scientific Conference on
[7] S. Mityakov, E. Mityakov, S. Morugin, L. Kulagina, "Method of generalized economic indicators calculation", 3rd International Multidisciplinary Scientific Conference on Social Sciences and Arts SGEM 2016, Albena, 2016, book 2, Vol. 4, pp. 409-416.

[8] V.V. Akberdina, A.V. Grebenkin, O.P. Smirnova, "Integrated tools for assessing the economic security of economic sectors: a regional aspect", Regional Economy, 2017, Vol. 13 (4) pp.1264-1279.

[9] S.N. Mityakov, E.S. Mityakov, N.A. Romanova, "Economic security of the Volga Federal District regions", Economy of the region, 2013, No. 3 (35), pp. 81-91.

[10] A.A. Korableva, "Economic security of the region in the system of regional security types: clarification of terminology", Bulletin of Tomsk State University, Economy, 2017, No. 40, pp.27-40.

[11] D.A. Maslennikov, S.N. Mityakov, L.Yu., Kataeva, T.A., Fedoseyeva, "Identification of the regions' strategic development on the statistical analysis basis of indicators", Regional Economy, 2019, Vol. 15 (3), pp.748-760. an agent-based model of the region" Society. Politics. Economy. Right, 2017, No. 12, pp. 101-104.

[13] O. V. Zhigalova, "Methodological support for assessing the economic 2017, No.1 (15), pp. 182-189.

[14] V.A. Tsvetkov, M.N. Dudin, N.V. Lyasnikov, "Analytical approaches and methods for assessing the economic security of a region", Regional Economy, 2019, Vol.15 (1), pp. 1-12.

[15] N.S. Abysheva, V.O., Tobolchina, "Economic security of the municipality. Society. Science. Innovation." [Electronic resource], Collection of papers: XIX All-Russia Scientific Practical Conference, Vyat-SU, 2019, pp. 22-27.

[16] O.B. Ganin, "Spatial aspects of the municipality economic security (on the example of the Aleksandrovsky municipal district of Perm region)", Regional Economics and Management [electronic journal], No. 4 (56), 2018, Article number 5612.

[17] E.V. Voloshenko, K.Yu. Voloshenko, "Indicators of sustainable rural development: a regional value", Bulletin of the Russian State University n.a. I. Kant, 2011, Vol. 21, pp. 117-124.

[18] E.S. Mityakov, T.A. Fedoseeva, "Economic security of municipalities (on the example of the Nizhny Novgorod region)", Security and Development, 2019, No. 4, pp. 93-104.

[19] Rostelecom created the first digital village in Russia, [Electronic resource], URL: https://cnews.ru/news/line/2018-1031_rostelekom_sozdal_pervoe_v_rossii_tsifrovoe.
[12] A.A. Nazarov, "Integral assessment of the economic security level using security level of municipalities", Regional Economy. South of Russia, 